\title{
The relationship between computer game addiction and obesity in third and fourth grade elementary school students
}

\author{
(1) Umut Kocakoğlu, (1) Nazan Karaoğlu, (1) Ruhuşen Kutlu \\ Necmettin Erbakan University, Meram Faculty of Medicine, Department of Family Medicine, Konya, Turkey
}

Date submitted:

18.05.2020

Date accepted:

02.10.2020

Online publication date:

15.06.2021

\section{Corresponding Author:}

Nazan Karaoğlu, Prof. M.D., Necmettin Erbakan University, Meram Faculty of Medicine, Department of Family Medicine, Konya, Turkey

ORCID:

orcid.org/0000-0002-3057-2988

Keywords: Children, computer game addiction, obesity

Presented in: This manuscript was presented orally in " $18^{\text {th }}$ National Family Medicine Congress 31 October-2 November 2019, Ankara" and published as an abstract form on page $62-63$ in the proceedings of the congress.

\begin{abstract}
Aims: Childhood obesity has been defined as a very serious public health issue. It was aimed to investigate the relationship between computer game addiction and obesity in $3^{\text {rd }}$ and $4^{\text {th }}$ grade elementary school students.

Methods: In this cross-sectional study, two separate questionnaires including demographic characteristics, physical activity, nutrition and computer game habits were applied to students and their parents. The students were also asked to fill the Computer Game Addiction Scale.

Results: This study included 491 children and parents. Above the half (51.5\%) were female and $69 \%$ were at normal weight. The body mass index (BMI) percentile values of children in the 8-9-year-old group were higher than those in the 10-11-year-old group ( $t=3.044 ; p=0.002)$. When children's computer game addiction was evaluated, it was found that while $86.9 \%$ of them were at low level of addiction, $12.7 \%$ were at moderate level of addiction. Having an overweight brother/sister, high paternal BMI, increase in time spent on screen, and low maternal education status increased BMI percentile values in children $(p<0.05)$. As long as the time of playing computer game increased, it was observed that BMI percentile values also increased significantly $(p=0.033)$.
\end{abstract}

Conclusions: This study shows that the level of computer game addiction and the time spent on screen are factors that increase obesity. In addition, the high level of frequency of snack in children is supportive of this result. If the ways to fight obesity are to promote physical activity and to move away from sedentary life style in children, it is clear that measures should be taken regarding the time that they spend in front of the screen.

\section{Introduction}

Childhood obesity has been defined as a very serious public health issue because it paves the way for the development of many chronic diseases. According to the 2016 report of World Health Organization (WHO), 340 million children in the age range of 5-19 years are either overweight or obese. The upsetting point is the prevalence of overweight. Obesity rate was $4 \%$ in the same age group in 1975, while it exceeded $18 \%$ in 2016 (1). According to a nationally comprehensive obesity study conducted on elementary school $2^{\text {nd }}$ grade students with the support of $\mathrm{WHO}$, the rates of obesity and overweight were $9.9 \%$ and $14.6 \%$, respectively (2). In a review investigating the studies in 2000-2010 all around Turkey, the prevalence of overweight and obesity in children at the age of 6-16 years was reported as $10.3-17.6 \%$ and $1.9-7.8 \%$, respectively (3).

There are many factors influencing childhood obesity. WHO has stated that the likelihood of a child being obese is $80 \%$ if both parents are obese, $40 \%$ if one parent is obese, and $14 \%$ if none of the parents are obese (4). This does not solely depend on genetic factors, nutritional habits of the family can also be effective along with cultural factors.

Various reasons leading to a child's being less active, decreased sports events and increased immobile activities can lead to a positive energy balance in children with similar nutrition. Activities with less physical demand such as watching TV, playing video games, and using the computer are closely 
related to obesity. AAP states that daily TV and computer use of children should be limited to a maximum of two hours (5). In a study performed on a thousand cases, $17 \%$ of adolescents who watched TV more than two hours a day during the week were overweight when they reached the age of 26 years (6). Socioeconomic status by itself is a risk factor for obesity; if it is low, there is imbalanced and erroneous nutrition and if it is high, there is over nutrition (7). Although the educational and occupational statuses of parents have been related to obesity in various manners, children grown in challenging life settings and bad conditions carry higher risk for obesity (8).

Although computer games have positive cognitive, emotional and social effects on children and adolescents, there are some negative physical effects, including obesity, as well as psychological and social negative effects. Similar to other behavioral addictions, game addiction is an extreme, compulsive, uncontrollable desire for playing game, resulting in psychological or physical harm (9). In a study performed in Australia, the relationship between obesity and watching TV and game addiction was stronger than the relationship between obesity and physical inactivity (10). A recent study from Afyon, Turkey, states that among 297 healthy students, 245 (82.5\%) were video game players. The rate of video game addiction was $1.6 \%$ in the whole sample, $3.1 \%$ aming the male students, and significantly high in obese children (9).

There have been various studies investigating the relationship between watching TV and obesity; nonetheless, studies on the relationship between computer game addiction and obesity are very limited. The present study aimed to analyze the relationship between computer game addiction and obesity in primary schools of Konya, which is a city with a high frequency of obesity.

\section{Methods}

This study was a cross-sectional study and its universe consisted of students attending the $3^{\text {rd }}$ and $4^{\text {th }}$ grades of elementary school in the center of Konya Province and their parents. The sample of the study was randomly formed by the three schools representing the students in Selcuklu, Meram and Karatay districts in accordance with the permission of the Provincial Directorate of National Education. The target sampling group consisted of at least 377 children and parents with 5\% error margin and 95\% confidence interval between February and May 2018. However, keeping the possibility of empty or incomplete questionnaires in mind, all data belonging to volunteering participants during the study period were included in the analyses. Inclusion criteria were as follows; being a student/student's parent of a school given permission by the Provincial Directorate of National Education, volunteering, being present at the school during the study period, having no chronic disease, no mental or physical impediments, having opportunity to reach computer games at home, at school, or outside, and having language, writing and expression skills sufficient enough to read, understand, and answer the questions.

Ethics Committee approval (no: 2018/1196, date: 09.02.2018) was taken from Necmettin Erbakan University Meram Faculty of Medicine and written permission was taken from the Provincial Directorate of National Education of Konya. Principals of the schools where the study was to be conducted were contacted and the study was performed with the consent of these principals and the support of school counselors.

Two separate questionnaires were prepared for children and parents. Both forms were given at the same number so that children and their parents were matched. The survey form prepared was first performed on 10 students and 10 parents as a pilot to assess possible problems regarding comprehensibility and practicality with the aim of making corrections accordingly and these data were not included in the main study.

The questionnaire form for children included questions about date of birth, gender, and status of playing computer games, along with Computer Games Addiction Scale for Children. The questionnaire form for parents included questions about familial educational status, family structure, height and body weight, socioeconomic status, along with questions about their children (nutrition, physical activity, sleep, time spent by technologic products like the television and computer).

Computer Game Addiction Scale (CGAS): It is developed by Horzum et al. (11) as a 5-point Likert scale consisting of 21 questions. There are 4 factors in the scale; 1) Not being able to quit/stop playing computer games, 2) Associating computer games with real life, 3) Disruption of tasks because of playing computer games, and 4) Opt for computer games over other activities. The scale is coded as 1 to 5 scores being "never", "rarely", "sometimes", "often", and "always". All questions in the scale are positive. The minimum and maximum scores to be taken from the scale are 21 and 105, respectively. While 21 to 49 scores indicate low levels of addiction, 50-77 shows moderate levels, and 78-105 shows high levels of computer game addiction (11).

Anthropometric measurements: For the evaluation of childhood obesity, the most frequent and practical method, the body mass index (BMI), was used. BMI is calculated by dividing body weight $(\mathrm{kg})$ by square of height (in meters) (BMI $=\mathrm{kg} /$ $\mathrm{m}^{2}$ ). However, as parameters change with age in children, BMI standards for age are used in school age children and adolescents, and percentiles and $z$ scores should also be taken into account (12). Thus, every child's BMI percentiles for age and gender were determined in accordance with the reference values of Neyzi et al. (13) standards while defining obesity categories. Accordingly, children under 5 percentiles were 
grouped as slim, 5-85 percentiles as normal, 85-95 percentiles as overweight, and over 95 percentiles as obese. In the present study, body weight and height measurements of the children were performed by the researcher. Height was calculated when the shoes were off, and the tape measure was attached to the wall while the child was looking forward in the most upright position possible. Body weight was determined by a digital scale sensitive to 100 grams, while facing forward in an upright position without shoes.

\section{Statistical Analysis}

The Statistical Package for Social Sciences for Windows 20.0 program was used for statistical analyses and evaluation of study findings. Definitive statistics of continuous variables were defined as mean and standard deviation while definitive statistics of categorical data were defined as frequency and percentage. Comparison of quantitative data with normal distribution was performed with the Independent Samples-t-test and one-way variance analysis (one-way ANOVA) test, while the Mann-Whitney $U$ and Kruskal-Wallis analyses were used for data with abnormal distribution. The chi-square test was used for comparison of categorical data and $p<0.05$ was considered statistically significant. Relationships between parameters were inquired with the Pearson's correlation analysis and the correlation coefficient ( $r$ ) was considered weak, moderate, strong, or very strong when between 0.00-0.24, 0.25-0.49, 0.500.74 , or $0.75-1.00$, respectively.

\section{Results}

A total of 491 children and parents were included in the study. School distribution of the participants was as follows: $32 \%$ $(n=157)$ from Karaarslan Cumhuriyet Primary School, 39.5\% $(n=194)$ from Zeliha Lutfi Kulluk Primary School, and 28.5\% $(n=140)$ from Mehmet Hasan Sert Primary School.

Gender and age distribution was as follows: $51.5 \%(n=253)$ were girls and $54.2 \%(n=266)$ were 9 years old. Normal body weight was encountered in $69 \%(n=339)$ and in this subgroup, more than half the mothers $(51.1 \%$; $n=251)$ were educated at primary school level or less. More than half $(62.1 \% ; n=305)$ of patients defined their economic status as moderate level. Sociodemographic features are given in Table 1.

Children's weekly physical activity time was $7.3 \pm 6.2$ hours, weekly number of breakfasts was $5.7 \pm 2.0$, number of regular consumption of 3 main courses per week was $5.2 \pm 2.3$, number of weekly take-home foods was $0.9 \pm 1.0$, and daily sleep time was $9.0 \pm 1.0$ hours. Snacking between main courses was a habit for $66 \%(n=326)$ of children while in $34 \%(n=99)$ of them, this habit was more frequent when they were facing electronic media devices. Physical activity and nutritional status are given in Table 2.

Table 1. Demographic features in accordance with parent forms

\begin{tabular}{|c|c|c|}
\hline Parameters & $\begin{array}{l}\text { Number } \\
\text { (n) }\end{array}$ & $\begin{array}{l}\text { Percentage } \\
(\%)\end{array}$ \\
\hline \multicolumn{3}{|l|}{ Age groups } \\
\hline 8 years old & 23 & 4.6 \\
\hline 9 years old & 266 & 54.2 \\
\hline 10 years old & 188 & 38.3 \\
\hline 11 years old & 14 & 2.9 \\
\hline \multicolumn{3}{|l|}{ Gender } \\
\hline Female & 253 & 51.5 \\
\hline Male & 238 & 48.5 \\
\hline \multicolumn{3}{|l|}{ School } \\
\hline $\begin{array}{l}\text { Karaarslan Cumhuriyet Primary } \\
\text { School }\end{array}$ & 157 & 32.0 \\
\hline Zeliha Lutfi Kulluk Primary School & 194 & 39.5 \\
\hline Mehmet Hasan Sert Primary School & 140 & 28.5 \\
\hline \multicolumn{3}{|l|}{ BMI classification of children } \\
\hline 0-5 percentile (slim) & 8 & 1.6 \\
\hline 5-85 percentile (normal) & 339 & 69.0 \\
\hline 85-95 percentile (overweight) & 70 & 14.3 \\
\hline Over 95 percentile (obese) & 74 & 15.1 \\
\hline \multicolumn{3}{|l|}{ Maternal BMI classification } \\
\hline$<18.5$ (slim) & 5 & 1.0 \\
\hline 18.5-24.99 (normal weight) & 218 & 44.4 \\
\hline 25.00-29.99 (overweight) & 195 & 39.7 \\
\hline 30 and more (obese) & 73 & 14.9 \\
\hline \multicolumn{3}{|l|}{ Paternal BMI classification } \\
\hline 18.5-24.99 (normal weight) & 162 & 33.0 \\
\hline 25.00-29.99 (overweight) & 240 & 48.9 \\
\hline 30 and more (obese) & 89 & 18.1 \\
\hline \multicolumn{3}{|l|}{ Presence of overweight siblings } \\
\hline Yes & 53 & 10.8 \\
\hline No & 438 & 89.2 \\
\hline \multicolumn{3}{|l|}{ Birth time of children } \\
\hline Term & 441 & 89.8 \\
\hline Preterm & 50 & 10.2 \\
\hline \multicolumn{3}{|l|}{ Maternal educational status } \\
\hline Illiterate & 16 & 3.3 \\
\hline Elementary school & 235 & 47.8 \\
\hline Secondary school & 170 & 34.6 \\
\hline High education & 70 & 14.3 \\
\hline \multicolumn{3}{|l|}{ Paternal educational status } \\
\hline Illiterate & 8 & 1.7 \\
\hline Elementary school & 174 & 35.4 \\
\hline Secondary school & 177 & 36.0 \\
\hline High education & 132 & 26.9 \\
\hline \multicolumn{3}{|l|}{ Economic status } \\
\hline Very good & 17 & 3.5 \\
\hline Good & 155 & 31.6 \\
\hline Moderate & 305 & 62.1 \\
\hline Bad & 12 & 2.4 \\
\hline Very bad & 2 & 0.4 \\
\hline BMI: Body mass index & & \\
\hline
\end{tabular}


Table 2. Features regarding children's physical activity and nutrition in accordance with parent forms

\begin{tabular}{lll}
\hline Parameters & Mean \pm SD & \\
\hline $\begin{array}{l}\text { Weekly physical activity time of } \\
\text { children (hours) }\end{array}$ & $7.3 \pm 6.2$ & \\
\hline $\begin{array}{l}\text { Weekly number of breakfasts of } \\
\text { children }\end{array}$ & $5.7 \pm 2.0$ & \\
\hline $\begin{array}{l}\text { Number of weekly consumption of } \\
\text { regular } 3 \text { main courses of children }\end{array}$ & $5.2 \pm 2.3$ & \\
\hline $\begin{array}{l}\text { Number of weekly consumption of } \\
\text { take-home food of children }\end{array}$ & $0.9 \pm 1.0$ & No \\
\hline $\begin{array}{l}\text { Daily sleeping time of children (hours) } \\
\text { Parameters }\end{array}$ & $9.0 \pm 1.0$ & Yes \\
\hline $\begin{array}{l}\text { Snacking status of children between } \\
\text { courses }\end{array}$ & $326(66 \%)$ & $165(29 \%)$ \\
\hline $\begin{array}{l}\text { In children, snacking between } \\
\text { courses. Whether or not they snacked } \\
\text { more frequently when facing electronic } \\
\text { media devices }\end{array}$ & $92(34 \%)$ & $399(71 \%)$ \\
\hline \begin{tabular}{l} 
SD: Standard deviation \\
\hline
\end{tabular} & & \\
\hline
\end{tabular}

While 22\% ( $n=108)$ had a computer and $2.9 \%(n=14)$ had a game console, the mean age for starting to play computer games was $7.0 \pm 1.4$ years and more than half $(57.9 \% ; n=260)$ played computer games both during the week and at the weekends. Children's use of electronic media devices in accordance with parent and children questionnaires are given in Table 3.

Before analyzing the relationship between age groups and BMI percentiles, some age groups were combined because there were a scarce number of children who were 8 and 11 years old, so 2 groups were formed for evaluation as those at the age of 8-9 years and those at the age of 10-11 years. The BMI percentile values of children in the 8-9-year-old group were higher than those in the 10-11-year-old group ( $t=3.044 ; p=0.002)$. There was no statistically significant relationship between gender and BMI percentiles $(t=0.598 ; p=0.550)$. Similarly, educational levels of parents were classified as 'primary school or less' and 'secondary school or more. Maternal educational level was significantly related to BMI percentiles $(t=0.389 ; p=0.038)$. Familial economic groups were defined as 'good' and 'moderate or bad'. Economic status was not significantly related to BMI percentiles ( $t=-0.263$; $\mathrm{p}=0.793$ ). Although time of birth had no significant relationship with BMI percentiles ( $t=0.767 ; p=0.443)$, having overweight siblings had $(t=2.872 ; p=0.004)$. The relationship between BMI percentiles and sociodemographic features is demonstrated in Table 4.

Grouping for obesity classification was defined as 'slim and normal', 'overweight', and 'obese'. Children's obesity status had no significant relationship with physical activity, eating weekly regular three course meals, weekly number of breakfasts, weekly consumption of take-home foods, daily sleeping hours,
Table 3. Demographic features regarding children's use of electronic media devices in accordance with parent and children forms

\begin{tabular}{|c|c|c|}
\hline Parameters & $\mathbf{n}$ & $\%$ \\
\hline \multicolumn{3}{|l|}{ Owning a computer* } \\
\hline Yes & 108 & 22.0 \\
\hline No & 383 & 78.0 \\
\hline \multicolumn{3}{|l|}{ Owning a tablet* } \\
\hline Yes & 227 & 46.2 \\
\hline No & 264 & 53.8 \\
\hline \multicolumn{3}{|l|}{ Owning a telephone* } \\
\hline Yes & 35 & 7.1 \\
\hline No & 456 & 92.9 \\
\hline \multicolumn{3}{|l|}{ Owning a game console* } \\
\hline Yes & 14 & 2.9 \\
\hline No & 477 & 97.1 \\
\hline Total & 491 & 100.0 \\
\hline Parameters & \multicolumn{2}{|c|}{ Mean $\pm S D$ (hours) } \\
\hline Mean daily time spent across the television* & \multicolumn{2}{|c|}{$2.1 \pm 1.2$} \\
\hline $\begin{array}{l}\text { Mean daily time for playing computer } \\
\text { games* }\end{array}$ & \multicolumn{2}{|c|}{$0.8 \pm 0.9$} \\
\hline $\begin{array}{l}\text { Mean daily time spent facing the computer } \\
\text { other than playing games* }\end{array}$ & \multicolumn{2}{|c|}{$0.7 \pm 0.8$} \\
\hline Mean daily time for playing tablet games* & \multicolumn{2}{|c|}{$0.5 \pm 0.7$} \\
\hline $\begin{array}{l}\text { Mean daily time spent facing the tablet other } \\
\text { than playing games* }\end{array}$ & \multicolumn{2}{|c|}{$0.5 \pm 0.7$} \\
\hline $\begin{array}{l}\text { Mean daily time spent playing telephone } \\
\text { games* }\end{array}$ & \multicolumn{2}{|c|}{$0.4 \pm 0.6$} \\
\hline $\begin{array}{l}\text { Mean daily time spent facing the telephone } \\
\text { other than playing games* }\end{array}$ & \multicolumn{2}{|c|}{$0.2 \pm 0.5$} \\
\hline $\begin{array}{l}\text { Mean daily time spent playing games with } \\
\text { the game console* }\end{array}$ & \multicolumn{2}{|c|}{$0.1 \pm 0.3$} \\
\hline
\end{tabular}

the game console*

Mean $\pm S D$ (years

Parameters old)

Mean age for starting to play computer $\quad 7.0 \pm 1.4$ games** $^{* *}$

Parameters

n $\%$

Status of playing computer games during the week and at the weekends**

\begin{tabular}{|c|c|c|}
\hline Only during the week & 21 & 4.7 \\
\hline Only weekends & 168 & 37.4 \\
\hline Both during the week and at the weekends & 260 & 57.9 \\
\hline Total & $449^{* * *}$ & 100 \\
\hline Parameters & \multicolumn{2}{|c|}{ Mean $\pm S D$ (hours) } \\
\hline $\begin{array}{l}\text { Mean daily time for playing computer games } \\
\text { during the } \text { week }^{\star *}\end{array}$ & \multicolumn{2}{|l|}{$0.9 \pm 1.0$} \\
\hline $\begin{array}{l}\text { Mean daily time for playing computer games } \\
\text { at the weekends**}\end{array}$ & \multicolumn{2}{|l|}{$1.4 \pm 1.0$} \\
\hline Parameters & $\mathbf{n}$ & $\%$ \\
\hline \multicolumn{3}{|l|}{$\begin{array}{l}\text { Place where computer games are mostly } \\
\text { played }^{* *}\end{array}$} \\
\hline Home & 422 & 94.0 \\
\hline School & 26 & 5.8 \\
\hline Other & 1 & 0.2 \\
\hline Total & $449^{* * *}$ & 100 \\
\hline \multicolumn{3}{|c|}{$\begin{array}{l}{ }^{*} \text { Evaluated in accordance with parent forms. } \\
{ }^{*} \text { Evaluated in accordance with children's forms. } \\
{ }^{* * *} \text { A total of } 42 \text { cases that did not play computer games were not taken into } \\
\text { account. } \\
\text { SD: Standard deviation }\end{array}$} \\
\hline
\end{tabular}




\begin{tabular}{|c|c|c|c|c|}
\hline Parameters & & $\begin{array}{l}\text { BMI percentile } \\
\text { Mean } \pm S D\end{array}$ & $\mathbf{t}$ & $\mathbf{p}^{*}$ \\
\hline \multirow{2}{*}{ Age group } & $\begin{array}{l}8-9 \text { years old } \\
(n=289)\end{array}$ & $65.4 \pm 27.2$ & \multirow[b]{2}{*}{3.044} & \multirow[b]{2}{*}{0.002} \\
\hline & $\begin{array}{l}10-11 \text { years } \\
\text { old }(n=202)\end{array}$ & $57.6 \pm 28.5$ & & \\
\hline \multirow[t]{2}{*}{ Gender } & $\begin{array}{l}\text { Female } \\
(n=258)\end{array}$ & $62.9 \pm 26.3$ & \multirow{2}{*}{0.598} & \multirow{2}{*}{0.550} \\
\hline & Male $(n=253)$ & $61.4 \pm 29.7$ & & \\
\hline \multirow{2}{*}{$\begin{array}{l}\text { Maternal } \\
\text { educational } \\
\text { level }\end{array}$} & $\begin{array}{l}\text { Primary school } \\
\text { or lower } \\
(n=251)\end{array}$ & $64.7 \pm 27.4$ & \multirow{2}{*}{0.389} & \multirow{2}{*}{0.038} \\
\hline & $\begin{array}{l}\text { Secondary } \\
\text { school or } \\
\text { higher }(n=240)\end{array}$ & $59.5 \pm 28.4$ & & \\
\hline \multirow{2}{*}{$\begin{array}{l}\text { Paternal } \\
\text { educational - } \\
\text { level }\end{array}$} & $\begin{array}{l}\text { Primary school } \\
\text { or lower } \\
(n=182)\end{array}$ & $63.5 \pm 28.4$ & \multirow{2}{*}{0.770} & \multirow{2}{*}{0.442} \\
\hline & $\begin{array}{l}\text { Secondary } \\
\text { school or } \\
\text { higher }(n=309)\end{array}$ & $61.4 \pm 27.6$ & & \\
\hline \multirow{2}{*}{$\begin{array}{l}\text { Economic } \\
\text { status }\end{array}$} & Good $(n=172)$ & $61.7 \pm 28.8$ & \multirow[b]{2}{*}{-0.263} & \multirow[b]{2}{*}{0.793} \\
\hline & $\begin{array}{l}\text { Moderate or } \\
\text { bad }(n=319)\end{array}$ & $62.4 \pm 27.6$ & & \\
\hline \multirow{2}{*}{ Birth time } & Term $(n=441)$ & $62.5 \pm 27.9$ & \multirow{2}{*}{0.767} & \multirow{2}{*}{0.443} \\
\hline & Preterm $(n=50)$ & $59.3 \pm 28.6$ & & \\
\hline \multirow{2}{*}{$\begin{array}{l}\text { Presence of } \\
\text { overweight } \\
\text { siblings }\end{array}$} & Yes $(n=53)$ & $72.5 \pm 26.6$ & \multirow[b]{2}{*}{2.872} & \multirow[b]{2}{*}{0.004} \\
\hline & No $(n=438)$ & $60.9 \pm 27.9$ & & \\
\hline \multirow{2}{*}{$\begin{array}{l}\text { Snacking } \\
\text { between } \\
\text { courses }\end{array}$} & Yes $(n=326)$ & $62.8 \pm 28.3$ & \multirow[b]{2}{*}{0.673} & \multirow[b]{2}{*}{0.501} \\
\hline & No $(n=165)$ & $61.0 \pm 27.3$ & & \\
\hline \multirow{2}{*}{$\begin{array}{l}\text { Snacking } \\
\text { status } \\
\text { while using } \\
\text { electronic } \\
\text { media }\end{array}$} & Yes $(n=92)$ & $66.2 \pm 28.2$ & \multirow[b]{2}{*}{1.528} & \multirow[b]{2}{*}{0.127} \\
\hline & No $(n=399)$ & $61.3 \pm 27.9$ & & \\
\hline
\end{tabular}

and daily time for watching TV $(p>0.05)$. On the other hand, obesity had a significant relationship with daily computer playing times $(p=0.005)$. Obesity was significantly related to CGAS scores $(p=0.049)$. The relationship between childhood obesity classification and some factors influencing obesity is given in Table 5.

Children's level of addiction was divided into 3 groups according to their CGAS scores as low (21-49 scores), moderate (50-77 scores), and high (78 and higher scores). A total of 42 cases that did not play computer games were not taken into account. Most of the children $(86.9 \%$; $n=390)$ had low levels of addiction. While $12.7(n=57)$ were moderately addicted, there were only 2 cases $(0.4 \%)$ who were found to be at high addiction level.

Between BMI percentile and daily total screen time $(r=0.122$; $p=0.007)$ and total CGAS scores $(r=0.126 ; p=0.008)$, a weak but positive correlation was determined. In addition, there was a weak but positive correlation between daily total screen time and total CGAS scores $(r=0.219 ; p<0.001)$.

\section{Discussion}

The present study is important, as it is the first study performed in Konya in this field and it has a wide sampling size with high numbers of students and parents. This study showed that $14.3 \%$ of the study group was overweight and $15.1 \%$ was obese as the Turkish Project of Monitoring Growth in School Children saying that $20.8 \%$ was overweight or obese in 6-10-year-old age group (14). Nonetheless, this means almost one in every five children is overweight or obese and this finding supports the serious risk of obesity that our Turkish Ministry of health has been warning about.

Studies performed abroad have revealed that the rate of computer game addiction in children and adolescents using computers is $9.3 \%$ in Singapore and $11.9 \%$ in Germany $(15,16)$. The present study revealed that levels of addiction were moderate in $12.7 \%$ of the children and high in $0.4 \%$. The increased ratios in our study suggest that computer game addiction has increased among children over the years.

In the literature, it is accepted that obesity in the family is one of the strongest risk factors for childhood obesity. In the present study, increased paternal BMI values were associated with increased childhood obesity. Maternal BMI values showed no statistically significant relationship with childhood obesity. In the study of Ohlund et al. (17), paternal obesity was defined as an independent risk factor for childhood obesity. The outcome for maternal BMI may be related to mothers reporting less than their actual weight, as data on parental weights are collected based on their report.

In the present study, when the relationship between paternal educational levels and BMI percentiles was investigated, maternal educational levels were found to be significantly associated while paternal levels showed no significant relationship. Huerta et al. (18) reported that similar low levels of parental education could misdirect children in terms of healthy nutrition and induce obesity by unbalanced and erroneous nutrition.

The presence of obese individuals within the family is thought to be a risk factor for childhood obesity and it is believed to be related to the genetic and environmental basis of obesity (4). Similarly, the present study found that BMI percentile values were related to the possibility of having an obese sibling. 


\begin{tabular}{|c|c|c|c|c|c|}
\hline & $\begin{array}{l}0-85 \text { percentile } \\
\text { Slim-normal (a) }\end{array}$ & $\begin{array}{l}85-95 \text { percentile } \\
\text { Overweight }(b)\end{array}$ & $\begin{array}{l}>95 \text { percentile } \\
\text { Obese (c) }\end{array}$ & \multirow{2}{*}{$\mathbf{F}$} & \multirow{2}{*}{ p } \\
\hline & $\begin{array}{l}\text { Mean } \pm S D \\
\text { Min-max }\end{array}$ & $\begin{array}{l}\text { Mean } \pm S D \\
\text { Min-max }\end{array}$ & $\begin{array}{l}\text { Mean士SD } \\
\text { Min-max }\end{array}$ & & \\
\hline \multirow{2}{*}{ Weekly physical activity time } & $7.3 \pm 6.1$ & $7.6 \pm 6.6$ & $7.1 \pm 5.9$ & \multirow{2}{*}{0.116} & \multirow{2}{*}{$0.944^{*}$} \\
\hline & $0-30$ & $1-28$ & $0-28$ & & \\
\hline \multirow{2}{*}{$\begin{array}{l}\text { Weekly number of eating regular } 3 \text { course } \\
\text { meals }\end{array}$} & $5.3 \pm 2.2$ & $4.8 \pm 2.4$ & $5.2 \pm 2.3$ & \multirow{2}{*}{2.143} & \multirow{2}{*}{$0.342^{*}$} \\
\hline & $0-7$ & $0-7$ & $0-7$ & & \\
\hline \multirow{2}{*}{ Weekly number of breakfasts } & $5.8 \pm 1.9$ & $5.4 \pm 2.2$ & $5.5 \pm 2.1$ & \multirow{2}{*}{3.983} & \multirow{2}{*}{$0.137^{*}$} \\
\hline & $0-7$ & $0-7$ & $0-7$ & & \\
\hline \multirow{2}{*}{$\begin{array}{l}\text { Weekly frequency of consumption of take- } \\
\text { home food }\end{array}$} & $0.9 \pm 1.0$ & $1.2 \pm 1.3$ & $0.9 \pm 1.1$ & \multirow{2}{*}{3.368} & \multirow{2}{*}{$0.186^{*}$} \\
\hline & $0-6$ & $0-7$ & $0-5$ & & \\
\hline \multirow{2}{*}{ Sleep time } & $9.0 \pm 1.0$ & $8.8 \pm 0.9$ & $9.0 \pm 0.9$ & \multirow{2}{*}{2.445} & \multirow{2}{*}{$0.295^{*}$} \\
\hline & $7-12$ & $7-11$ & $7-12$ & & \\
\hline \multirow{2}{*}{ Daily time spent watching TV } & $2.1 \pm 1.2$ & $2.3 \pm 1.1$ & $2.1 \pm 1.3$ & \multirow{2}{*}{1.873} & \multirow{2}{*}{$0.392^{*}$} \\
\hline & $0-6$ & $0-5$ & $0-5$ & & \\
\hline \multirow{2}{*}{ Daily time spent playing computer games } & $0.7 \pm 0.8$ & $1.1 \pm 1.1$ & $1.0 \pm 1.2$ & \multirow{2}{*}{11.864} & \multirow{2}{*}{$0.005^{\mathrm{ab}^{*}}$} \\
\hline & $0-5$ & $0-4$ & $0-5$ & & \\
\hline \multirow{2}{*}{$\begin{array}{l}\text { Daily computer activity time other than } \\
\text { game playing }\end{array}$} & $0.6 \pm 0.8$ & $0.7 \pm 0.9$ & $0.7 \pm 0.8$ & \multirow{2}{*}{1.757} & \multirow{2}{*}{$0.415^{*}$} \\
\hline & $0-5$ & $0-4$ & $0-3$ & & \\
\hline \multirow{2}{*}{ Daily time spent playing tablet games } & $0.6 \pm 0.8$ & $0.5 \pm 0.7$ & $0.5 \pm 0.7$ & \multirow{2}{*}{0.096} & \multirow{2}{*}{$0.953^{*}$} \\
\hline & $0-5$ & $0-3$ & $0-3$ & & \\
\hline \multirow{2}{*}{$\begin{array}{l}\text { Daily tablet activity time other than game } \\
\text { playing }\end{array}$} & $0.5 \pm 0.7$ & $0.4 \pm 0.8$ & $0.5 \pm 0.8$ & 2325 & $0212 *$ \\
\hline & $0-5$ & $0-3$ & $0-4$ & 2.320 & 0.310 \\
\hline Daily time spent plaving telephone games & $0.4 \pm 0.6$ & $0.5 \pm 0.6$ & $0.4 \pm 0.6$ & & \\
\hline Dany time spent praying terepnone games & $0-4$ & $0-2$ & $0-3$ & 3.825 & $0.148^{n}$ \\
\hline Daily telephone activity time other than & $0.2 \pm 0.4$ & $0.3 \pm 0.6$ & $0.2 \pm 0.4$ & 3.794 & $0.150^{*}$ \\
\hline game playing & $0-3$ & $0-2$ & $0-1$ & & \\
\hline Daily time spent playing games on the & $0.1 \pm 0.3$ & $0.1 \pm 0.4$ & $0.1 \pm 0.3$ & 0.481 & $0786^{*}$ \\
\hline game console & $0-2$ & $0-2$ & $0-1$ & & \\
\hline Maternal BMI $\left(\mathrm{kg} / \mathrm{m}^{2}\right)$ & $25.7 \pm 4.2$ & $26.0 \pm 4.4$ & $26.5 \pm 4.0$ & 1.180 & $0.308^{* *}$ \\
\hline Paternal BMI $\left(\mathrm{kg} / \mathrm{m}^{2}\right)$ & $26.4 \pm 3.4$ & $27.2 \pm 3.4$ & $28.3 \pm 4.1$ & 10.227 & $<0.001^{\mathrm{ac}^{* t}}$ \\
\hline $\begin{array}{l}\text { Total daily time spent facing the screen } \\
\text { (hours) }\end{array}$ & $5.2 \pm 2.6$ & $6.0 \pm 2.7$ & $5.7 \pm 2.9$ & 3.834 & $0.033^{\mathrm{ab}^{* *}}$ \\
\hline Total CGAS scores & $35.6 \pm 11.0$ & $39.3 \pm 12.7$ & $38.3 \pm 11.5$ & 3.489 & $0.049^{a b^{* *}}$ \\
\hline $\begin{array}{l}{ }^{*} \text { The Kruskal-Wallis test was used for analyses and } \\
{ }^{* *} \text { One-way ANOVA test was used and in cases of dif } \\
\text { aSlim-normal. } \\
\text { bOverweight. } \\
\text { "Obese. } \\
\text { CGAS: Computer Game Addiction Scale, SD: Stand }\end{array}$ & deviation, BMI: Bod & $\begin{array}{l}\text { the groups, the non- } \\
\text { ost-hoc (Tukey) test }\end{array}$ & $\begin{array}{l}\text { metric post-hoc (Dun } \\
\text { used. }\end{array}$ & test was 4 & \\
\hline
\end{tabular}

In the present study, BMI percentile values were higher in children who were snacking frequently between main courses; however, the difference was not statistically significant. Similarly, Özilbey and Ergör (19) found no significant relationship between snacking between main courses and BMI percentile values in elementary school students and snacking between main courses is a variable that affects obesity in adults. Yet, it can be thought that despite the influence, it is not a prominent factor in childhood period.

BMI percentiles of children showed no significant relationship with physical activity. The studies performed by Öztora (20) in 2005 and Koçoğlu et al. (21) in 2003 showed that the duration of weekly sports activities was not related to obesity. However, individuals who do not sufficiently engage in physical activities 
are known to be more obese when compared to individuals who engage in high levels of physical activity. In addition, it is a well-known fact that obese individuals engage in lower levels of physical activity. In the present study, the results can be because the activity presented could not objectively be evaluated in accordance with the suggestions of the American Academy of Pediatrics (5).

In the literature, there are various studies supported and unsupported by the claims that weekly regular three course main meals and weekly number of breakfasts are interrelated with obesity. The present study, similar to the study performed by Özilbey and Ergör (19), found that having breakfast was not related to obesity. Contrary to this, another study reported that obesity was more frequent in students who skipped main courses (22). These different results can depend on the content of breakfast. As a matter of fact, a breakfast including plenty of carbohydrates and fats can increase the risk of obesity. This situation shows that regular courses by themselves do nott mean much as their content should also be questioned in details.

The present study could not reveal a significant relationship between BMI percentiles and weekly consumption of take-home foods. This finding was similar to the studies of Özilbey and Ergör (19) and Savaşhan et al. (23) in which no significant relationship between obesity and frequency of consumption of fat food could be revealed. Miller (24), on the other hand, remarked that limiting consumption of fast food/quick bites, sweetened beverages, and snacks was an important step in preventing obesity. Children who skip main courses can turn to high calorie fast food at the school or outside and this in turn can lead to obesity. The reason for this variable not being significantly related to obesity in the present study can be generally low frequency of fast food consumption in the studied population.

Some studies indicate a positive relationship between screen time across the television and obesity while others state that there is no significant relationship $(20,21)$. A study performed in United States in 2008 revealed that screen time and BMI was not related but prolonged high attention and orientation to the television led to increased BMI values. Same researchers reported that consuming energy-loaded food during the time when primary attention was concentrated on the television was related to obesity (25). Similarly, in the present study, there was no significant relationship between daily time of watching TV and BMI percentiles and the reason of this could be the relationship of appetite and obesity with attention and concentration on the television rather than screen watching time.

In the present study, the increase in daily time of playing computer games led to increased BMI percentile values in children. Goldfield et al. (26) performed a study in 2011 and stated that playing computer games was significantly related to blood pressure and blood lipid levels. Researchers reported that video game playing, which was investigated in well-controlled laboratory research, could lead to high blood pressure and high blood lipid levels because of its leading to spontaneous food and energy-loaded snack consumption. In addition, this same study showed that the stress, concentration, and other acute reasons resulting from the wish to play an effective game during video gaming increased heart rate, blood pressure, and sympathetic tonus, along with increased mental activity when compared to resting. Other authors depending on this abovementioned conclusion stated that computer games leading to increased sympathetic activity could lead to the consumption of high calorie food and thus affect obesity.

The BMI percentile values and total daily screen time of our children were interrelated. In a study performed in the US, it was stated that this relationship led to exposure to encouraging ads to eat and was associated with unwitting consumption of food with high calorie and high sugar content (27). In the present study, levels of computer game addiction increased along with BMI percentile values. Turel et al. (28) also found that computer game addiction and obesity were interrelated and explained this relationship with computer games encouraging sleep deprivation and direction to snacks by using ads. Karimi and Ghorbani (29) performed a study on a total of 2,195 children in the age group of 6-12 years in 2015 and concluded that computer games led to obesity by decreasing physical activity.

The present study revealed that total daily screen time and computer game addiction were significantly related. Another similar study suggested that pathological game addicts spent twice longer screen time when compared to non-addicts (30). Nevertheless, electronic media devices like the television, computer, tablet, telephone, and the game console reinforce the relationship between each other by acting as a supporting infrastructure and it can be thought that the brain activates its dopamine-related reward system, hence game addiction.

This study has some limitations. First of all, its cross sectional design and getting information from this age group with a questionnaire may create biases. For controlling age bias, we also got information from parents. Schools were selected with the permission of the Provincial Directorate of National Education. So, different school students might give different results but because of randomly selection, we thought that this study group might represent the whole. Accessing data, especially getting their weight and height, may have bias but in the present study, body weight and height measurements of the children were performed by the same researcher.

\section{Conclusions}

In this study, in addition to other obesity studies in the literature, obesity-related factors in children were investigated extensively in Konya, a city with a high obesity rate. The presence of overweight siblings, increased paternal BMI, increased total screen time, and low maternal educational status were found to increase the risk of obesity. 
Childhood obesity is known to develop as a result of genetic and environmental factors. One of the important factors due to its interchangeability is inactivity. Children addicted to computer games have decreased physical activity, decreased sleep time and quality, direct to high calorie food because of the ads they are exposed to and thus their obesity risk becomes suggestive. Nowadays, due to increased access to computers in every home, the relationship between computer games and obesity becomes more important. When investigating the relationship between computer games and obesity, the levels of addiction should also be taken into account along with screen times. In our country, while there are studies involving the relationship between obesity and the duration of playing games, it is important to note that more studies are needed to investigate the relationship between obesity and computer game addiction. Computer game addiction is essential in terms of the possible future results of obesity. There is a need to raise awareness of families, schools and the whole community on this issue. Ensuring a safe environment and green spaces for children should be a national policy.

\section{Acknowledgements}

This paper and the research behind it would not have been possible without the exceptional support of all faculty, residents and staff of Family Medicine Department of Meram Medical Faculty.

\section{Ethics}

Ethics Committee Approval: Ethics Committee Approval (no: 2018/1196, date: 09.02.2018) was taken from Necmettin Erbakan University Meram Faculty of Medicine and written permission was taken from the Provincial Directorate of National Education of Konya.

Informed Consent: Principals of the schools where the study was to be conducted were contacted and the study was performed with the consent of these principals and the support of school counselors.

Peer-review: Externally peer-reviewed.

\section{Authorship Contributions}

Surgical and Medical Practices: U.K., R.K., Concept: U.K., N.K., R.K., Design: U.K., N.K., Data Collection or Processing: U.K., Analysis or Interpretation: N.K., R.K., Literature Search: U.K., N.K., Writing: U.K., N.K., R.K.

Conflict of Interest: No conflict of interest was declared by the authors.

Financial Disclosure: The authors declared that this study received no financial support.

\section{References}

1. World Health Organization. Obesity and overweight. Fact sheet $311 ; 2017$. Available from: https://www.who.int/newsroom/fact-sheets/detail/obesity-and-overweight

2. "Türkiye Çocukluk Çağı (İlkokul 2. Sınıf Öğrencileri) Şişmanlık Araştırması - COSI-TUR 2016" Sağlık Bakanlığı, Halk Sağlığı Genel Müdürlüğü, Milli Eğitim Bakanlığı, Dünya Sağlık Örgütü Avrupa Bölge Ofisi, Sağlık Bakanlığı Yayın No: 1080, Ankara 2017

3. Bereket A, Atay Z. Current status of childhood obesity and its associated morbidities in Turkey. J Clin Res Pediatr Endocrinol. 2012;4:1-7.

4. World Health Organization. Obesity: preventing and managing the global epidemic report of a WHO consultation on obesity. Geneva, World Health Organ Tech Rep Ser. 2000;894:1-253.

5. Krebs NF, Jacobson MS; American Academy of Pediatrics Committee on Nutrition. Prevention of pediatric overweight and obesity. Pediatrics. 2003;112:424-430.

6. Hancox RJ, Milne BJ, Poulton R. Association between child and adolescent television viewing and adult health: a longitudinal birth cohort study. Lancet. 2004;364:257-262.

7. Murasko JE. Trends in the associations between family income, height and body mass index in US children and adolescents: 1971-1980 and 1999-2008. Ann Hum Biol. 2011;38:290-306.

8. Gnavi R, Spagnoli TD, Galotto C, Pugliese E, Carta A, Cesari L. Socioeconomic status, overweight and obesity in prepuberal children: a study in an area of Northern Italy. Eur J Epidemiol. 2000;16:797-803.

9. Oflu A, Yalcin SS. Video game use among secondary school students and associated factors. Arch Argent Pediatr. 2019;117:e584-e591.

10. Maher C, Olds TS, Eisenmann JC, Dollman J. Screen time is more strongly associated han physical activity with overweight and obesity in 9- to 16-year-old Australians. Acta Paediatr. 2012;101:1170-1174.

11. Horzum MB, Ayas T, Çakırbalta Ö. Çocuklar için bilgisayar oyun bağımlılığı ölçeği. Türk Psikolojik Danışma ve Rehberlik Dergisi. 2008;3:76-88.

12. Köksal G, Özel HG. Çocukluk ve ergenlik döneminde obezite. T.C. Sağlık Bakanlığı Yayın No: 729 Ankara: Klasmat Matbaacılık; 2008.

13. Neyzi $O$, Günoz H, Furman A. Türk çocuklarında vücut ağırlığı, boy uzunluğu, baş çevresi ve vücut kitle indeksi referans değerleri. Türkiye Çocuk Hast Derg. 2008;5:1-14.

14. Türkiye'de Okul Çağı Çocuklarında (6-10 yaş grubu) Büyümenin İzlenmesi (TOÇBI) Projesi Araştırma Raporu. Ankara: Kuban Matbaacılık Yayıncılık; 2011.

15. Choo H, Gentile DA, Sim T, Li D, Khoo A, Liau AK. Pathological video-gaming among Singaporean youth. Ann Acad Med Singapore. 2010;39:822-829. 
16. Grüsser SM, Thalemann R, Griffiths MD. Excessive computer game playing: evidence for addiction and aggression? Cyberpsychol Behav. 2007;10:290-292.

17. Ohlund I, Hernell O, Hörnell A, Stenlund H, Lind T. BMI at 4 years of age is associated with previous and current protein intake and with paternal BMI. Eur J Clin Nutr. 2010;64:138145.

18. Huerta M, Bibi H, Hahiv J, Scharf S, Gdalevich M. Parental smoking and education as determinants of overweight in Israeli children. Prev Chronic Dis. 2006;3:1-9.

19. Özilbey P, Ergör G. Determining the prevalence of obesity in primary school students and eating habits in Izmir. Turk J Public Health. 2015;13:30-39.

20. Öztora S. Estimating the prevalence of obesity and related risk factors for the primary school children. Bakırköy Tıp Dergisi. 2006;2:11-14.

21. Koçoğlu G, Özdemir L, Sümer H, Demir DA, Çetinkaya S, Polat $\mathrm{HH}$. Prevalence of obesity among 11-14 years old students in Sivas-Turkey. Pakistan J Nutr. 2003;2:292-295.

22. Turan T, Ceylan SS. Researching of obesity prevelance and dietary pattern in vocational high school students. TAF Prev Med Bull. 2009;8:5-12.

23. Savaşhan Ç, Sarı O, Aydoğan Ü, Erdal M. Obesity frequency in primary school children. Türk Aile Hek Derg. 2015;19:14-21.
24. Miller DP. Associations between the home and school environments and child body mass index. Soc Sci Med. 2011;72:677-684.

25. Bickham D, Blood E, Walls C, Shrier L, Rich M. Characteristics of screen media use associated with higher BMI in young adolescents. Pediatrics. 2013;131:935-941.

26. Goldfield GS, Kenny GP, Hadjiyannakis S, Phillips P, Alberga AS, Saunders TJ, et al. Video game playing is independently associated with blood pressure and lipids in overweight and obese adolescents. PLoS One. 2011;6:e26643.

27. Falbe J, Rosner B, Willett WC, Sonneville KR, Hu FB, Field $\mathrm{AE}$. Adiposity and different types of screen time. Pediatrics. 2013;132:1497-1505.

28. Turel O, Romashkin A, Morrison KM. A model linking video gaming, sleep quality, sweet drinks consumption and obesity among children and youth. Clin Obes. 2017;7:191198.

29. Karimi B, Ghorbani R. Overweight and obesity in the Iranian schoolchildren. East J Rehabil Health. 2015;2:e24433.

30. Gentile D. Pathological video-game use among youth ages 8 to 18: a national study. Phsycol Sci. 2009;20:594-602. 